\title{
MICELLAR PROPERTIES OF CETYLTRIMETHYLAMMONIUM BROMIDE IN AN ACETONITRILE-WATER MIXTURE: CONDUCTOMETRIC AND FLUORESCENCE STUDIES
}

\author{
Aleksandra Janošević Ležaićc ${ }^{*}$, Nataša Pejić ${ }^{1}$, Jelena Goronja ${ }^{2}$ Leposava Pavun $^{1}$, \\ Danijela Đikanovićc ${ }^{3}$, Anđelija Malenović ${ }^{2}$ \\ ${ }^{1}$ Faculty of Pharmacy, University of Belgrade, Department of Physical Chemistry and \\ Instrumental Methods, Vojvode Stepe 450, 11000 Belgrade, Serbia \\ ${ }^{2}$ Faculty of Pharmacy, University of Belgrade, Department of Drug Analysis, \\ Vojvode Stepe 450, 11000 Belgrade, Serbia \\ ${ }^{3}$ University of Belgrade - Institute for Multidisciplinary Research, \\ Kneza Višeslava 1, 11030 Belgrade, Serbia
}

The effect of acetonitrile (ACN) on the micellization of a cationic surfactant, cetyltrimethylammonium bromide (CTAB), in aqueous solutions at different temperatures was studied. The critical micellar concentration (CMC) as well as the degree of counter ion dissociation $(\alpha)$ of CTAB in aqueous ACN mixtures $(10-20 \% \mathrm{v} / \mathrm{v})$ at various temperatures $(291.2-298.2 \mathrm{~K})$ were determined by electrical conductivity measurements, while steady-state fluorescence measurements were used to determine several CMCs (for comparison) and a micellar aggregation number $\left(N_{\mathrm{agg}}\right)$ as well. At a fixed temperature, both an increase in CMC and a decrease in $N_{\text {agg }}$ were observed for an increase in ACN in the solvent mixture. With a temperature increase, CMC values increased for $10 \%(\mathrm{v} / \mathrm{v}) \mathrm{ACN}$, while for both $15 \%$ and $20 \%$ (v/v) ACN, CMC values were a minimum at $T=295.2 \mathrm{~K}$ with a temperature increase. In addition, some aspects related to the Krafft temperature behavior of CTAB in the examined micellar systems are discussed.

Keywords: acetonitrile/water mixtures; cetyltrimethylammonium bromide; conductometry;

critical micellar concentration; steady-state fluorescence measurements

\section{МИЦЕЛАРНИ СВОЈСТВА НА ЦЕТИЛТРИМЕТИЛАМОНИУМ БРОМИД ВО СМЕСАТА ОД АЦЕТОНИТРИЛ ВОДА: КОНДУКТОМЕТРИСКИ И ФЛУОРЕСЦЕНТНИ СТУДИИ}

Беше испитано влијанието на ацетонитрилот (ACN) врз мицелизацијата на катјонски сурфактант, цетилтриметиламониум бромид (СТАВ), во водна средина на различни температури. Со помош на мерења на електричната спроводливост, беа определени критичната мицеларна концентрација (СМС), и степенот на дисоцијација на спротивните јони $(\alpha)$ на СТАВ во водни смеси на ACN (10-20\% v/v) на различни температури (291,2-298,2 K), додека за определување на неколку СМС (за споредба), како и на мицеларен агрегационен број $\left(N_{\mathrm{agg}}\right)$ беа употребени рамнотежни флуоресцентни мерења. На фиксна температура беше забележано зголемување на CMC и намалување на $N_{\text {agg }}$ со зголемување на ACN во смесата на растворот. Со зголемување на температурата вредностите на СМС се зголемија за $10 \%$ (v/v) ACN, додека за $15 \%$ и за $20 \%$ (v/v) $\mathrm{ACN}$, вредностите на СMC при зголемување на температурата на $T=295,2 \mathrm{~K}$ беа минимални. Покрај тоа, дискутирани се некои аспекти што се поврзани со однесувањето на температурата на Krafft на СТАВ во испитуваните мицеларни системи.

Клучни зборови: смеси ацетонитрил/вода; цетиламониум бромид; кондуктометрија; критична мицеларна концентрација; рамнотежни флуоресцентни мерења 


\section{INTRODUCTION}

The association of surfactant monomers into finite-sized aggregates, as micelles are, is probably the most interesting aspect of these molecules, and surfactant self-aggregation remains one of the main topics of study within interface science and colloid chemistry. Besides studies related to the spontaneous aggregation of surfactants in aqueous media, there are numerous reasons why these examinations in nonaqueous polar solvents as well as in aqueousorganic mixed solvents have attracted great attention [1-3]. Namely, these investigations allow the consideration of many significant surfactant physicochemical properties, which are of tremendous interest for their potential applications in both industry and everyday life (as cleaners, solubilizers, lubricants, antistatic agents, etc.) [4-6]. Among the many applications, modern instrumental techniques, such as micellar liquid chromatography (MLC), micellar electrokinetic chromatography (MEKC), and cloud point extraction (CPE) are particular examples of effective applications of micellar systems.

When dispersed in a given medium under certain conditions (solvent, temperature, etc.), surfactants undergo self-aggregation (micellization) at a specific surfactant concentration called the critical micelle concentration (CMC). Hence, surfactants make microheterogeneous supramolecular structures (micelles) that exist in dynamic equilibrium with the surfactant monomers (or ions) from which the micelle is formed. Aside from the CMC, the other most significant parameter in studies dealing with micellization of surfactants is a micellar aggregation number (the average number of surfactant monomers that aggregate into a micelle, $N_{\text {agg }}$ ). In order to determine their values, a number of physico-chemical techniques have been conveniently employed [7-9]. For a particular surfactant, in addition to temperature, $\mathrm{pH}$, and pressure, the presence of additives, such as a cosolvent, cosurfactants, and electrolytes, also has a significant influence on the micelle formation in an aqueous solution [5]. Recently published papers on the micellization of surfactants show that researchers are more interested in micelle formation in mixed solvent systems rather than in pure ones $[2,3,10$ 17]. For investigations of micellization of various surfactants in water-organic solvent mixtures, the most common methodology based on gradual exchange of water (WR) for another (polar) solvent was used. Thus, changing solvent characteristics provides the opportunity to modulate the aggregation behavior of a particular surfactant either by modifying the bulk-phase properties (so-called solvophobic effect) in mixed solvents or by solvent incorporation in the micelles $[2,3,9,11,12,15-$ 18]. These examinations have numerous intentions, from a fundamental investigation in order to understand cosolvent influence on micellar and physicochemical properties of surfactants, to the application in certain areas (lubrication, cleaning operation, etc.) where the presence of water is undesirable.

Within the many studies on the surfactant micellization in different aqueous binary mixtures of various organic solvents, hexadecyltrimethylammonium bromide (hereinafter cetyltrimethylammonium bromide, $\mathrm{CTAB}$ ) was very often the object of the research $[2,3,9,11,16,19-22]$ considering that it is widely used in various fields, such as the chemical and pharmaceutical industries. Among these comprehensive studies, there are only a few papers related to the examination of the micellar behavior of CTAB in aqueous acetonitrile [3, 20, 23]. For those examinations, electrical conductivity measurements at different temperatures were used. Nevertheless, in continuation of our interest in investigating the behavior of CTAB $[17,21,22]$, in this manuscript, we present and discuss the results obtained from conductometric and fluorescence studies of CTAB self-aggregation properties in ACN/WR mixtures with different cosolvent compositions (10-20\% v/v) since ACN is generally used as an organic additive to the mobile phase for selectivity adjustment of solutes in micellar liquid chromatography [24] as well as micellar electrokinetic chromatography [25]. Electrical conductivity and steady-state fluorescence quenching (SSFQ) measurements were used to determine both the CMC and $N_{\text {agg }}$ over a temperature range of 291.2-298.2 K. In addition, an attempt was also made to discuss the effect of ACN on the self-aggregation of CTAB through thermodynamic analysis. The temperature dependence of both the CMC and the degree of counterion dissociation $(\alpha)$ was used to estimate various thermodynamic parameters as well as enthalpy-entropy compensation phenomenon. Also, some aspects related to the Krafft temperature behavior of $\mathrm{CTAB}$ in the examined micellar systems, i.e., the transition in those systems in the vicinity of the Krafft temperature $\left(T_{\mathrm{K}}\right)$, were discussed. For such purposes, conductivity experiments were employed, and a conductivity hysteresis was found.

\section{EXPERIMENTAL SECTION}

\subsection{Materials}

All chemicals were of analytical grade and were used without further purification. The cationic surfactant, cetyltrimethylammonium bromide 
(purity $\geq 97 \%$ ), and the fluorescent probe, pyrene (Pyr) (purity $\geq 99 \%$ ), were used as received from Sigma-Aldrich (USA). Acetonitrile (ACN) (HPLC grade purity $\geq 99.9 \%$ ) as the organic solvent and cetylpyridinium chloride (CPC) (purity $\geq 98 \%$ ) as the quencher were obtained from J.T. Baker (USA) and Krka (Slovenia), respectively. Deionized water having a specific resistance of $18 \mathrm{M} \Omega \mathrm{cm}$ (i.e., specific conductivity of $0.05 \mu \mathrm{S} \mathrm{cm} \mathrm{cm}^{-1}$ ) (Milli-Q, Millipore, Bedford, MA, USA) was used to prepare all solutions.

The fresh solutions of CTAB in ACN/water binary mixtures $(10: 90,15: 85$, and $20: 80$ by volume) were prepared by dissolving a certain mass of CTAB in $90 \mathrm{ml}$ of 10,15 , or $20 \%$ (v/v) ACN; those mixtures were softly stirred with a glass rod to avoid foaming. Finally, the solutions were transferred in a $100 \mathrm{ml}$ volumetric flask and kept for at least $15 \mathrm{~min}$ under thermostated conditions (291.2, 295.2, and $298.2 \mathrm{~K}$ ) before being filled up to volume with 10 , 15 , or $20 \%(\mathrm{v} / \mathrm{v}) \mathrm{ACN}$. Standard solutions were prepared daily no more than $3 \mathrm{~h}$ prior to their use by being dissolved in appropriate solvents.

\subsection{Methods}

\subsubsection{Conductometric measurements}

The CMC as well as $T_{\mathrm{K}}$ of the examined micellar systems were determined by electrical conductivity measurements. These measurements were made using a digital conductivity meter HI8820N (Hanna instruments, Portugal) with the uncertainties $\pm 0.5 \mu \mathrm{S} \mathrm{cm}^{-1}$ as well as with a HI7684W conductivity probe that used the 4-ring method. The conductivity cell was calibrated with different concentrations of potassium chloride solutions (Merck, purity $>99 \%$ ) prior to the experiment. Conductivity measurements were carried out in a $100 \mathrm{ml}$ thermostated glass vessel (Metrohm Model 876-20) that was equipped with a magnetic stirrer (IKA-COMBIMAG RET, Staufen, Germany). The temperature was controlled within $\pm 0.1 \mathrm{~K}$ using a water bath (HANYOUNG NUX, Korea).

Determination of the CMC and the degree of counterion dissociation. The conductivity-concentration data were obtained from three micellar systems, i.e., CTAB in ACN/water binary mixtures $(10,15$, and $20 \% \mathrm{v} / \mathrm{v})$. At a fixed solvent composition, the specific conductance was measured for different concentrations of CTAB; $90 \mathrm{ml}$ of the examined solution was placed in a glass vessel thermostated ( $20 \mathrm{~min})$ at the desired temperature (291.2, 295.2 , or $298.2 \mathrm{~K}$ ) and constantly stirred at a rate $r=$ $300 \mathrm{rpm}$. These specific conductance measurements were repeated three times for each solution and temperature. In order to study the effect of both the cosolvent and temperature on the CTAB micellization process, the above procedure was repeated for any particular ACN composition and temperature over the examined temperature range.

For the precise determination of the CMC values, the method suggested by Carpena et al. [26] was applied. This method is based on direct fitting of the experimental raw data into a function obtained by direct integration of the Boltzmann type sigmoid function. The fitting procedure is described in detail elsewhere $[21,22]$. Determination of the CMC was carried out through a fitting procedure of the experimental conductivity data $(\kappa)$ as a function of CTAB concentration $(c)$ according to the equation:

$\kappa=\kappa_{(0)}+A_{1} c+\left(A_{2}-A_{1}\right) \Delta c \ln \left(\frac{1+\mathrm{e}^{\left(c-c_{0}\right) / \Delta c}}{1+\mathrm{e}^{-c_{0} / \Delta c}}\right)$

where $\kappa_{(0)}$ is the specific conductivity at zero CTAB concentration, $A_{1}$ and $A_{2}$ are pre- and postmicellar slopes, respectively, and $\Delta c$ is the width of transition whose central point, $c_{0}$, corresponds to the $\mathrm{CMC}$.

In addition to values of CMC, $A_{1}$, and $A_{2}$, the values of the degree of counterion dissociation $(\alpha$ $=A_{2} / A_{1}$ ) were obtained from fittings of the specific conductivity-concentration plots to equation (1).

Determination of the Krafft temperature. To determine $T_{\mathrm{K}}$ of CTAB in aqueous ACN, $6.0 \times$ $10^{-2} \mathrm{M}$ CTAB solutions were prepared in ACN/WR binary mixtures (10-20\% v/v). These solutions were cooled, i.e., placed in a refrigerator at a temperature of about $4{ }^{\circ} \mathrm{C}$ for at least $24 \mathrm{~h}$, which is where the precipitation of surfactant hydrated crystals occurs. The temperature of each precipitated system was first increased and then decreased in the temperature range from $5{ }^{\circ} \mathrm{C}$ to $28^{\circ} \mathrm{C}$ at a rate of 2 ${ }^{\circ} \mathrm{C} / 10 \mathrm{~min}$ and under continuous stirring $(r=300$ $\mathrm{rpm}$ ); for each temperature, the specific conductivity of the solution was measured several times for about 3 min after reaching a steady value. $T_{\mathrm{K}}$ was taken as the temperature at which the specific conductivity

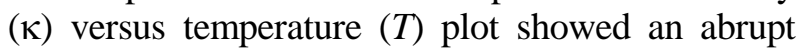
change in slope [27-29].

\subsubsection{Fluorescence measurements}

Fluorescence measurements were carried out on a model Fl3-221 P spectrofluorometer (JobinYvon, Horiba, France) equipped with a $450 \mathrm{~W}$ Xe lamp (as an excitation source) and photomultiplier tube (as detector). Both excitation and emission slit widths were set to $1 \mathrm{~nm}$. Steady-state fluorescence measurements were performed at several temperatures (291.2-298.2 K) using a Peltier element. The 
experimental error in the temperature was minimized to $\pm 0.1{ }^{\circ} \mathrm{C}$. The excitation wavelength was $335 \mathrm{~nm}$. The emission spectra were recorded in the range of $350-500 \mathrm{~nm}$ at a scan speed of $60 \mathrm{~nm} \mathrm{~min}{ }^{-1}$.

Determination of the CMC by the pyrene 1:3 ratio method. In order to obtain the $\mathrm{CMC}$, fluorescence spectra of the examined micellar systems of different compositions, i.e., solutions with different CTAB concentrations $(0.2-5.6 \mathrm{mM})$ and a constant Pyr concentration $(1 \mu \mathrm{M})$ in water (WR) at $298.2 \mathrm{~K}$ and ACN/WR binary mixtures $(10-20 \% \mathrm{v} / \mathrm{v})$ at 291.2 K, were acquired. The first and third vibrionic peak of the Pyr fluorescence spectra appeared at 373 $\mathrm{nm}$ and $384 \mathrm{~nm}$, respectively, and their corresponding intensities ( $I_{1}$ and $I_{3}$, respectively) were used for evaluating the $\mathrm{CMC}$. The $\mathrm{CMC}$ value was obtained from the intersection point of the extrapolation of the descending and horizontal parts of the $I_{1} / I_{3}$ vs. CTAB concentration curve $[9,30]$.

Determination of the average aggregation number by the steady-state fluorescence quenching (SSFQ) method. The average aggregation number $\left(N_{\mathrm{agg}}\right)$ of CTAB in aqueous ACN of three compositions $(10-20 \% \mathrm{v} / \mathrm{v})$ and at several temperatures (291.2-298.2 K) was determined by performing SSFQ using CPC as the quencher [18, 31]. For determining $N_{\text {agg }}$, solutions with constant concentrations of both Pyr $(2 \mu \mathrm{M})$ and CTAB $(20 \mathrm{mM})$ were prepared. Then, fluorescence quenching at the desired temperature was done by the addition of CPC whose concentration varied in the range of $0-100$ $\mu \mathrm{M} . N_{\text {agg }}$ was calculated from the slopes of the linear plot of $\ln \left(I_{0} / I_{\mathrm{Q}}\right)$ versus quencher concentration ([Q]) using the following equation [31]:

$$
\ln \frac{I_{0}}{I_{\mathrm{Q}}}=\frac{N_{\mathrm{agg}}}{[S]-\mathrm{CMC}}[Q]
$$

where $I_{0}$ and $I_{\mathrm{Q}}$ are the Pyr fluorescence intensities in the absence and presence of the quencher at a wavelenght of $384 \mathrm{~nm}$, respectively, while [S] is the total surfactant $(\mathrm{CTAB})$ concentration.

\subsubsection{Data analysis}

All experimental data were processed (fitted) using the software package OriginPro 9.0 (OriginLab Corporation, US).

\section{RESULTS AND DISCUSSION}

\subsection{Critical micellar concentration of CTAB}

The CMC values of the examined micellar systems, i.e., CTAB in ACN/WR binary mixtures $(10-20 \% \mathrm{v} / \mathrm{v})$ at several temperatures (291.2-
$298.2 \mathrm{~K}$ ), were obtained by using conductivity measurements. Some typical plots of specific conductivity ( $\kappa)$ of a CTAB solution at a fixed composition of $\mathrm{ACN}$ versus $\mathrm{CTAB}$ concentration $(c)$ at different temperatures are shown in Fig. 1. For all the examined micellar systems, $\kappa-c$ plots were obtained that are comprised of two linear segments (premicellar and postmicellar), i.e., two straight lines with different slopes. From those $\kappa-c$ plots, by using data treatment described elsewhere [21, $22,26]$, both the CMC and $\alpha$ were derived, and all the values are summarized in Table 1.

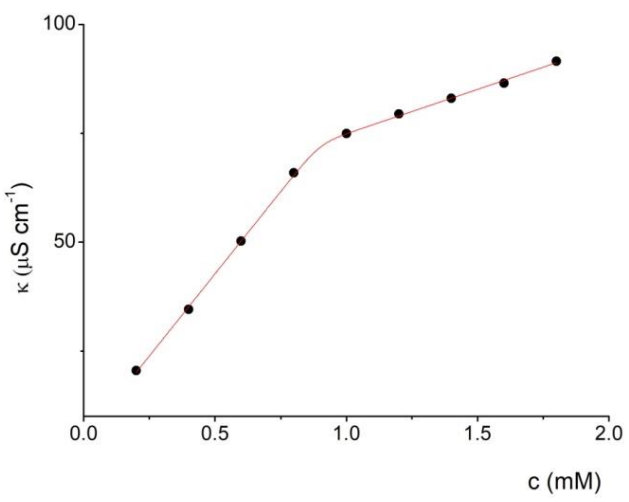

(a)

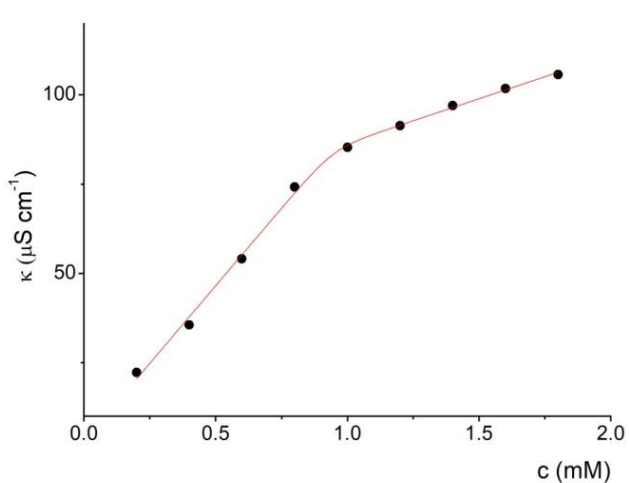

(b)

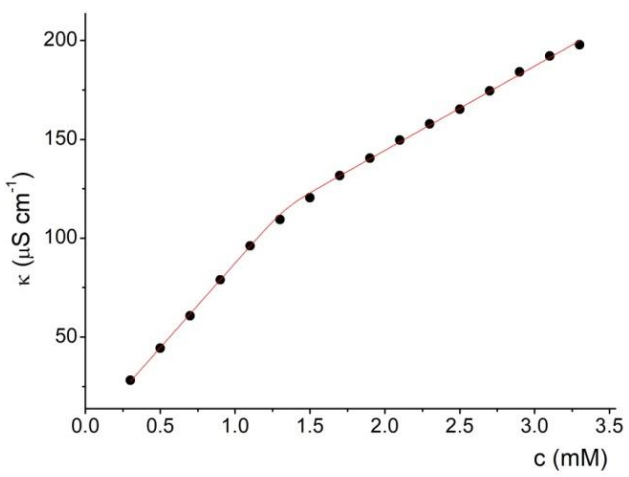

(c)

Fig. 1. Representative plots of specific conductivity $(\kappa)$ versus CTAB concentration $(c)$ in an ACN/WR mixture $(10 \% \mathrm{v} / \mathrm{v})$ at different temperatures: $291.2 \mathrm{~K}$ (a), $295.2 \mathrm{~K}$ (b), and $298.2 \mathrm{~K}$ (c). The best fits of the obtained $\kappa-c$ data to Eq. (1) [22] are represented by solid lines. 
For comparison of the results, the pyrene 1:3 ratio method (Fig. 2) was also used to acquire a few CMC values, and those were the CMC of CTAB in both water at $298.2 \mathrm{~K}$ and $\mathrm{ACN} /$ water binary mixtures $(10-20 \% \mathrm{v} / \mathrm{v})$ at $291.2 \mathrm{~K}$. The ob- tained CMC values are all listed in Table 1. As shown in Table 1, there is acceptable agreement between the CMC values obtained from the conductance and pyrene 1:3 ratio methods, confirming the validity of our measurements.

\section{Table 1}

Critical micellar concentration (CMC) and degree of counterion dissociation $(\alpha)$ of CTAB in both water at $298.2 \mathrm{~K}$ and ACN/WR mixtures at different temperatures as well as the dielectric constant $(\varepsilon)$ of those systems

\begin{tabular}{c|c|c|c|c|c}
\hline \hline \multirow{2}{*}{$\begin{array}{c}\text { Acetonitrile } \\
(\% \mathrm{v} / \mathrm{v})\end{array}$} & \multirow{2}{*}{$\begin{array}{c}\text { Temperature } \\
(\mathrm{K})\end{array}$} & $\varepsilon^{\mathrm{a}}$ & \multicolumn{2}{|c|}{ CMC (mM) } & \multirow{2}{*}{$\alpha$} \\
\cline { 4 - 6 } & 298.2 & 78.33 & $0.91^{\mathrm{b}}$ & 1.06 & $0.39^{\mathrm{b}}$ \\
\hline 0 & 291.2 & 78.23 & 0.90 & 1.18 & 0.27 \\
\multirow{3}{*}{10} & 295.2 & 76.80 & 0.95 & - & 0.28 \\
& 298.2 & 75.28 & 1.33 & - & 0.50 \\
\hline \multirow{3}{*}{15} & 291.2 & 76.53 & 1.72 & 1.53 & 0.73 \\
& 295.2 & 75.14 & 1.60 & - & 0.84 \\
& 298.2 & 74.11 & 1.82 & - & 0.78 \\
\hline \multirow{3}{*}{20} & 291.2 & 74.61 & 3.16 & 3.41 & 0.61 \\
& 295.2 & 73.25 & 3.10 & - & 0.55 \\
& 298.2 & 72.25 & 4.42 & - & 0.55 \\
\hline \hline
\end{tabular}

${ }^{a}$ Value calculated from the empirical equation given in ref. [32]

${ }^{\mathrm{b}}$ Values taken from ref. [22].

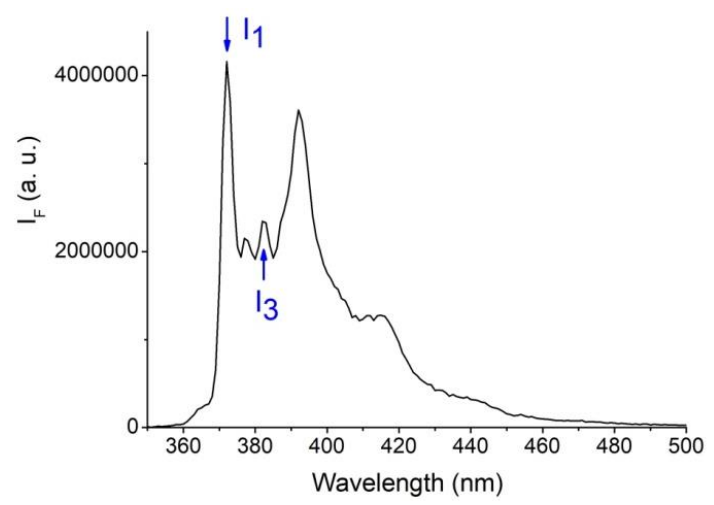

(a)

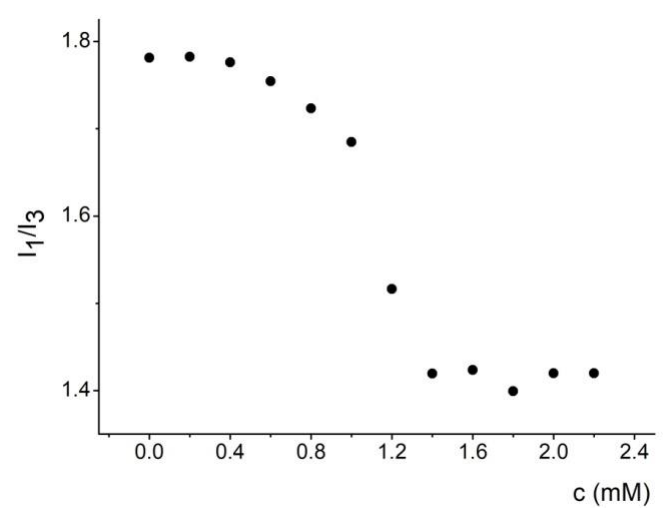

(c)

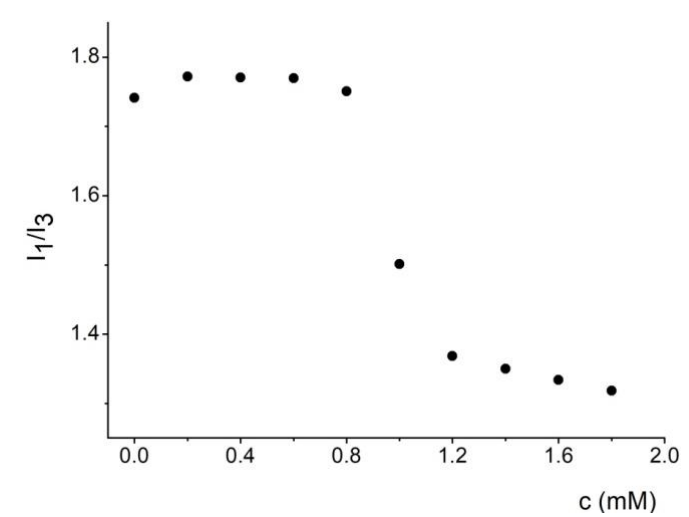

(b)

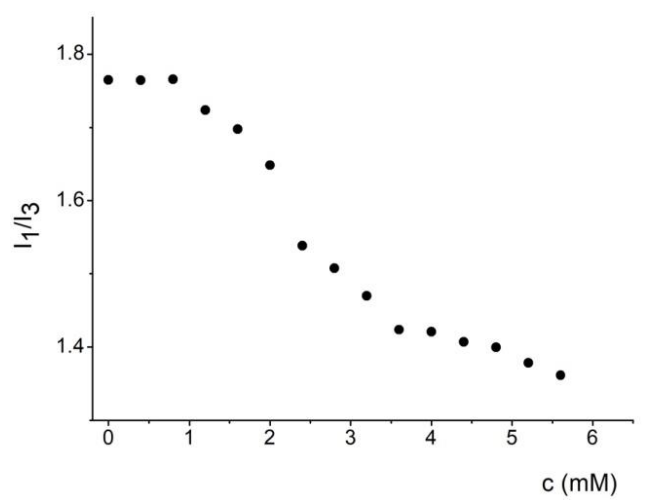

(d)

Fig. 2. Fluorescence spectrum of aqueous $\mathrm{CTAB}$ solution with $1 \mu \mathrm{M}$ pyrene (a) together with plots of $I_{1} / I_{3}$ versus concentration of CTAB at different ACN volume fractions: $10 \%$ (b), $15 \%$ (c), and $20 \%(\mathbf{d}) ; T=291.2 \mathrm{~K}$. 
It is worth mentioning that both the $\mathrm{CMC}$ and $\alpha$ values in pure water (Table 1) agree with previously reported values obtained by conductivity measurements at $T=298.2 \mathrm{~K}[3,16,22,33]$. The data in Table 1 show that at a given temperature, the $\mathrm{CMC}$ value increases with increasing $\mathrm{ACN}$ content in the solvent mixture, which is, generally, a trend in any water-polar organic solvent mixture. Furthermore, the obtained trend of $\mathrm{CMC}$ changes is in agreement with previously reported results related to the effect of ACN on the micellization of some surfactants $[3,13,15,20,23]$, which can be explained by the following facts: the very presence of ACN causes a decrease in water polarity that enhances the solubility of the hydrocarbon tail of the surfactant monomer as well as provokes a reduction in the dielectric constant (Table 1), causing mutual repulsion among the charged head groups in the micelle. All of this leads to a delayed micellization, i.e., the $\mathrm{CMC}$ increases.

Also, a perusal of the data in Table 1 indicates the increase in the CMC values with a temperature increase for $\mathrm{ACN}$-poor mixtures (water and $10 \% \mathrm{ACN})$. On the other hand, for $15 \%$ as well as for $20 \%$ can, with a temperature increase within the investigated temperature range, the CMC values have a minimum at $T=295.2 \mathrm{~K}$. It is well known that this type of behavior (the so-called U-shaped behavior) is attributed to most surfactants above a certain temperature [5]. For CTAB in pure water, the presence of a similar minimum was reported $[34,35]$; the temperature of the minimum CMC $\left(T_{\mathrm{m}}\right)$ of aqueous CTAB is $293 \pm 0.5 \mathrm{~K}$ based on conductometric data reported by Kumar et al. [35], whereas Noudeh et al. managed to obtain a $T_{\mathrm{m}}$ of $297.5 \mathrm{~K}$ from tensiometric measurements [34]. The effect of temperature on the CMC of surfactants in different aqueous media is rather complex: with a temperature increase over a particular temperature range, the CMC can increase or decrease depending on the relative magnitude of two opposite effects, one that promotes micellization and the other that leads to its delay. Namely, a temperature increase can result in a decrease in the hydration of the surfactant hydrophilic group (favoring effect) but also a breakdown of the structured water surrounding the surfactant hydrophobic group (disfavoring effect) [5].

The results related to $\alpha$ (Table 1) showed that at a fixed temperature and with an increase in the ACN content, the $\alpha$ values increased initially followed by an abrupt decrease. On the other hand, for a fixed solvent composition, with an increase in temperature, the $\alpha$ values of CTAB in $10 \% \mathrm{ACN}$ increased, whereas the temperature effect on other micellar systems (CTAB in both $15 \%$ and $20 \%$ $\mathrm{ACN}$ ) was not regular, and in those cases, neither an increase nor a decrease can be seen (Table 1). However, note that the $\alpha$ value is related to the surface area per head group $\left(a_{0}\right)$ in the ionic micelle [5]; the larger surface area per head group (the lower charge density on the micellar surface), the greater the value of $\alpha$ will be. The $\alpha$ characterizes the electrostatic interactions between the charged surface of the micelles and counterions that very closely surround the micellar surface, which depends mainly on the properties of the particular medium in which the micellization process of a specific surfactant occurs. Therefore, $\alpha$ can be influenced by the addition of a cosolvent in the background solvent medium $[12,15,36]$. In addition, it should be emphasized that the degree of micellar ionization of some ionic surfactants, including $\mathrm{CTAB}$ in aqueous binary mixtures with different organic solvents (formamide, acetonitrile, etc.), increases with increasing organic solvent composition $[12,20]$, regardless of whether the solvent causes a decrease or increase in the bulk phase permittivity. As pointed out previously [12, $15,20]$, this increase in $\alpha$ can be attributed to a decrease in the $N_{\text {agg }}$ caused by the addition of some organic solvent, thus reducing the electrostatic repulsion between surfactant head groups (that effect prevails over the effect of polarity changes of the medium), which leads to a reduction in the electrical charge density on the micellar surface.

In addition, the effect of ACN on CTAB micellization at $298.2 \mathrm{~K}$ can be also discussed through the so-called free energy of transfer,

$$
\Delta G_{\mathrm{T}}^{0}=\left(\Delta G_{\mathrm{m}}^{0}\right)_{\mathrm{ACN} / \mathrm{WR}}-\left(\Delta G_{\mathrm{m}}^{0}\right)_{\mathrm{WR}}[37],
$$

where $\left(\Delta G_{\mathrm{m}}^{0}\right)_{\mathrm{ACN} / \mathrm{WR}}$ and $\left(\Delta G_{\mathrm{m}}^{0}\right)_{\mathrm{WR}}$ are changes of standard molar Gibbs free energy of CTAB micellization in an ACN/WR mixture and water, respectively.

The standard molar Gibbs free energy change of micellization $\left(\Delta G_{\mathrm{m}}{ }^{0}\right)$ can be calculated from the following relationship [5]:

$$
\Delta G_{\mathrm{m}}^{0}=(2-\alpha) R T \ln X_{\mathrm{CMC}},
$$

where $\alpha$ is the degree of counterion dissociation, $R$ is the gas constant, $T$ is the temperature (in $\mathrm{K}$ ), and $X_{\mathrm{CMC}}$ is the mole fraction of the surfactant at the CMC [5].

The following standard molar Gibbs free energy change of CTAB micellization at $298.2 \mathrm{~K}$ was obtained (equation 3): $-44.10 \mathrm{~kJ} \mathrm{~mol}^{-1}$ (water), $-45.94 \mathrm{~kJ} \mathrm{~mol}^{-1}(10 \% \mathrm{ACN}),-31.60 \mathrm{~kJ} \mathrm{~mol}^{-1}(15$ $\% \mathrm{ACN})$, and $-32.44 \mathrm{~kJ} \mathrm{~mol}^{-1}(20 \% \mathrm{ACN})$. Thus, 
at certain ACN compositions in aqueous mixture, the $\left(\Delta G_{\mathrm{m}}^{0}\right)_{\mathrm{ACN} / \mathrm{WR}}$ values are: $4.80 \mathrm{~kJ} \mathrm{~mol}^{-1}(10 \%$ $\mathrm{ACN}), 13.20 \mathrm{~kJ} \mathrm{~mol}^{-1}$ (15\% ACN), and $10.67 \mathrm{~kJ}$ $\mathrm{mol}^{-1}(20 \% \mathrm{ACN})$. As Rodríguez et al. emphasized [12], the addition of an organic solvent facilitates dissolution of the surfactant monomer in the bulk phase, which further impairs the incorporation of a hydrophobic tail into the micelle, leading to an increase in the CMC. Thus, the obtained positive values $\Delta G_{T}^{0}$ confirm the increase in the CTAB hydrocarbon tail solubility in the presence of $\mathrm{ACN}$ as well as the decrease in the solvophobic effect. The above described behavior was also reported for tetradecyltrimethylammonium bromide in an ethylene glycol/water binary mixture [10] and CTAB in a propylene glycol/water binary mixture [17].

\subsection{Krafft temperature of $C T A B$ in aqueous $A C N$}

It is well known that for ionic surfactants, there is a certain temperature, the so-called Krafft temperature (Krafft point) [28, 38] or the critical micellar temperature [39], at which the surfactant monomers are sufficiently soluble to initiate aggregation/micellization. Below the Krafft temperature $\left(T_{\mathrm{K}}\right)$, the surfactant monomers become insoluble in water and do crystallize out of solution as a hydrated crystal. For a particular surfactant, $T_{\mathrm{K}}$ depends on both the surfactant concentration and the presence of different additives (electrolyte, cosolvents, etc.) $[29,38]$. However, the $T_{\mathrm{K}}$ is a considerably important parameter for establishing the appropriate temperature range in which micellization is investigated; knowing the value of $T_{\mathrm{K}}$ is essential since below $T_{\mathrm{K}}$, the surfactant loses its extraordinary characteristics, such as its detergency and micelle forming properties, which certainly limits their applications in certain processes. For practical use, it is desirable to decrease the $T_{K}$ of surfactants, which can be accomplished by tailoring the molecular structure of the surfactants or by introducing suitable additives to adjust the aqueous environment.

The Krafft temperatures of CTAB in ACN/WR binary mixtures $(10-20 \% \mathrm{v} / \mathrm{v})$ were measured through conductivity experiments (see experimental) and practically determined as described in [40]. The change in the specific conductivities $(\kappa)$ with temperature $(T)$ of $6.0 \times 10^{-2} \mathrm{M}$ $\mathrm{CTAB}(\approx 60 \mathrm{CMC})$ in aqueous acetonitrile was measured in the temperature range of 285.2-313.2 $\mathrm{K}$ (Fig. 3, Ia, Ib, and Ic) and vice-versa (Fig. 3, IIa, IIb, and IIc). $T_{\mathrm{K}}$ corresponds to the upper break in the $\kappa-T$ plots (Figs. 3a, b, and c) as well as to the visually observed clarification of the CTAB suspension. The following $T_{\mathrm{K}}$ values were obtained:
293.2 K (10 \% ACN, Fig. 1a), 287.2 K (15\% ACN, Fig. 1b), and 283.2 K (20\% ACN, Fig. 1c).

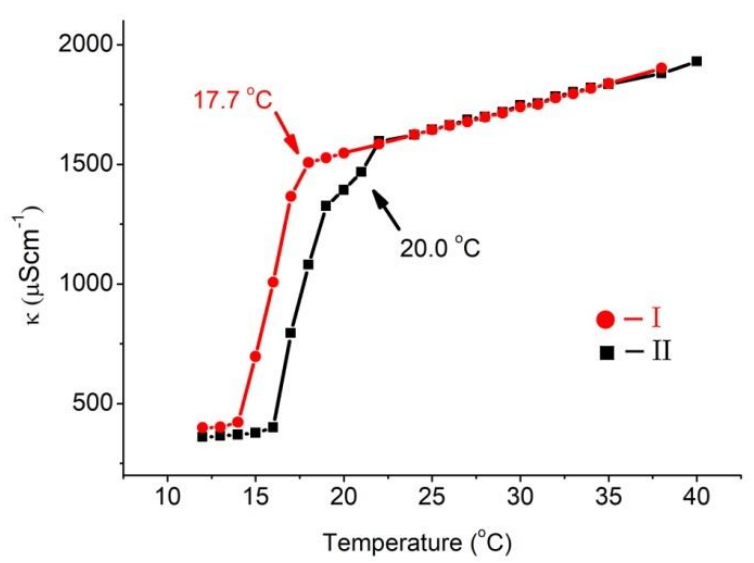

(a)

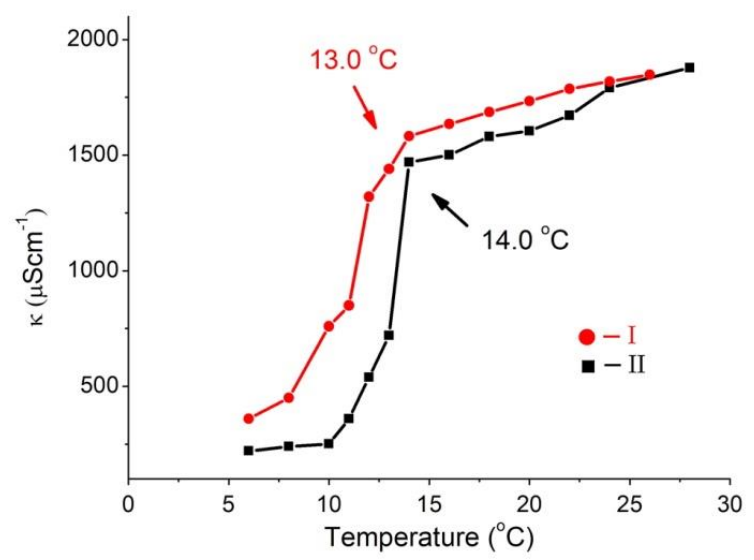

(b)

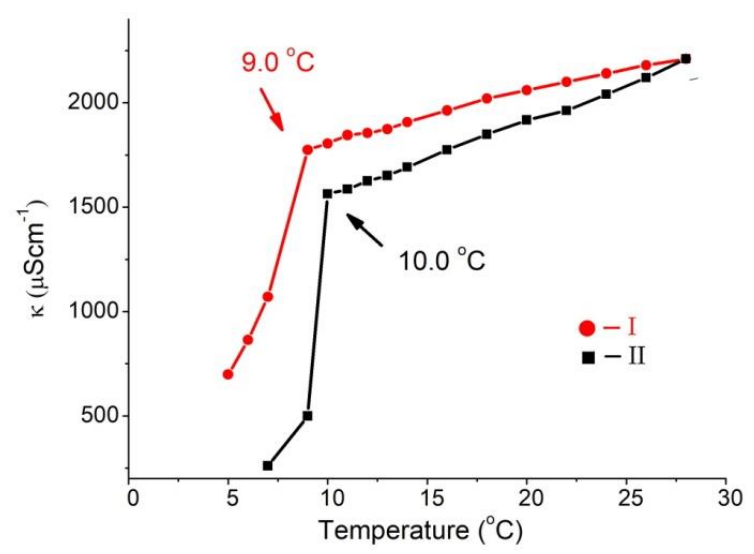

(c)

Fig. 3. The Krafft temperature $\left(T_{\mathrm{K}}\right)$ of $6.0 \times 10^{-2} \mathrm{M} \mathrm{CTAB}$ in ACN/WR mixtures at different ACN volume fractions: (a) $10 \%$, (b) $15 \%$, and (c) $20 \%$; lines I and II correspond to specific conductivity data obtained in increasing (I) and decreasing (II) temperatures.

Note that the Krafft temperatures of CTAB in $\mathrm{ACN} / \mathrm{WR}$ mixtures were generally found to be below the conventional value for CTAB in pure water (as examples: $T_{\mathrm{K}}=299 \mathrm{~K}$ [35] and $T_{\mathrm{K}} \approx 300 \mathrm{~K}$ [27]). Also, for CTAB in $10 \% \mathrm{ACN}$, the $T_{\mathrm{K}}$ that was at- 
tained is close to some values that were reported in pure water (ranges from about $20^{\circ} \mathrm{C}$ to $27^{\circ} \mathrm{C}$ ) [27, 41]. On the other hand, for CTAB in both $15 \%$ and $20 \% \mathrm{ACN}$, the large decrease of the $T_{\mathrm{K}}$ was obtained. However, the acquired values of the Krafft temperatures for $\mathrm{CTAB}$ in different mixing ratios of ACN established a lower temperature, which is a limit for our studies on these micellar systems.

Moreover, for a CTAB concentration above the $\mathrm{CMC}\left(6.0 \times 10^{-2} \mathrm{M} \approx 60 \mathrm{CMC}\right)$ in the examined micellar systems, the hysteresis of conductivity with respect to temperature was noticed (Fig. 3). The results given in Figure 3 (curve II a, b, and c) were obtained in conductivity experiments where the temperature changed in the opposite direction, i.e., where the temperature decreased from 313.2 to $285.2 \mathrm{~K}$. Thus, by varying the temperature in both directions, by first increasing the temperature and then decreasing the temperature after the system has passed through the Krafft point, it was established that the $T_{\mathrm{K}}$ occurred at different temperature values when approached from either side, i.e., hysteresis was observed. The same phenomenon has already been obtained and discussed in aqueous CTAB solutions [28]. In any event, at this stage of our work, the detailed characterization of the hysteretic behavior of $\mathrm{CTAB}$ aqueous $\mathrm{ACN}$ is beyond the scope of this paper and will be the target of future investigations.

\subsection{Structural characteristic of the CTAB micellar system}

The micelle aggregation number $\left(N_{\mathrm{agg}}\right)$ is the most important parameter related to the structural characteristic of a micellar system since it contains information on the micelle size and shape under the actual experimental conditions. To investigate the effect of ACN on $N_{\text {agg }}$ of CTAB micelles, the well-established SSFQ measurements were used $[18,31,42]$ (see experimental). The micelle aggregation number of CTAB in both water and the ACN/WR binary mixtures calculated from the slopes of the obtained linear plots, $\left.\ln \left(I_{0} / I_{\mathrm{Q}}\right)\right)=([Q])$ (see the insert in Fig. 4.), are all summarized in Table 2. The errors in $N_{\text {agg }}$ in terms of the standard deviation of three individual determinations are estimated to be less than $6 \%$.

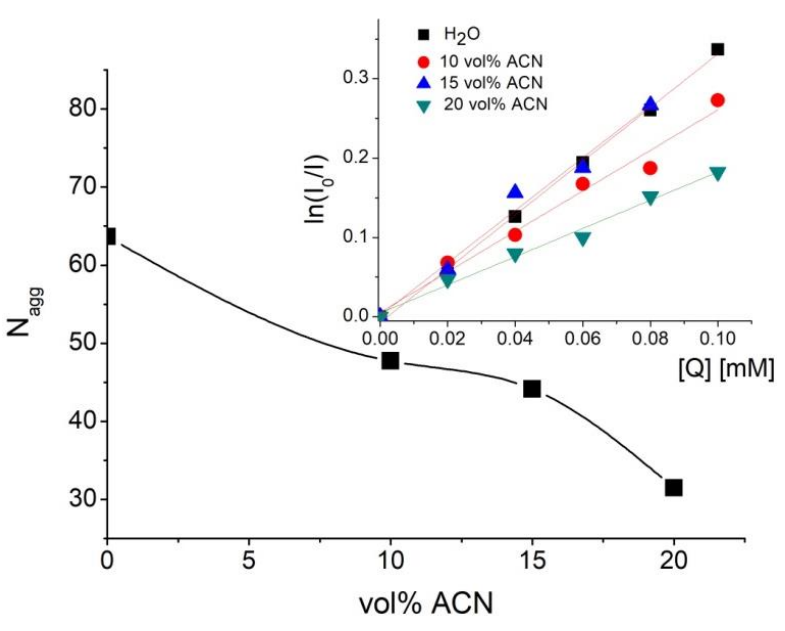

Fig. 4. The aggregation number $\left(N_{\mathrm{agg}}\right)$ versus the volume fraction of ACN in mixed solutions (vol\% $\mathrm{ACN}$ ) at $T=295.2 \mathrm{~K}$. Insert: Plots of $\ln \left(I_{0} / I_{\mathrm{Q}}\right)$ at $384 \mathrm{~nm}$ versus concentration of the quencher $[Q]$; concentration of CTAB is $20 \mathrm{mM}$.

Table 2

Micelle aggregation number $\left(N_{a g g}\right)$, radius $\left(R_{0}\right)$, surface area per head group $\left(a_{0}\right)$, and packing parameter $\left(P=v / a_{0} l_{c}\right)$ of CTAB micelles in both water at $298.2 \mathrm{~K}$ and $A C N /$ water mixed media at different temperatures

\begin{tabular}{cccccc}
\hline $\begin{array}{c}\text { Acetonitrile } \\
(\% \mathrm{v} / \mathrm{v})\end{array}$ & $\begin{array}{c}T \\
(\mathrm{~K})\end{array}$ & $N_{\mathrm{agg}}$ & $\begin{array}{c}R_{0} \\
(\mathrm{~nm})\end{array}$ & $\begin{array}{c}a_{0} \\
\left(\mathrm{~nm}^{2}\right)\end{array}$ & $\begin{array}{c}P \\
\left(v / a_{0} l_{\mathrm{c}}\right)\end{array}$ \\
\hline 0 & 298.2 & 77 & 2.03 & 0.675 & 0.31 \\
\hline \multirow{2}{*}{10} & 291.2 & 61 & 1.88 & 0.730 & 0.29 \\
& 295.2 & 48 & 1.73 & 0.790 & 0.27 \\
& 298.2 & 41 & 1.65 & 0.833 & 0.25 \\
\hline \multirow{2}{*}{15} & 291.2 & 46 & 1.71 & 0.802 & 0.26 \\
& 295.2 & 44 & 1.69 & 0.814 & 0.26 \\
& 298.2 & 44 & 1.69 & 0.814 & 0.26 \\
\hline \hline & 291.2 & 27 & 1.44 & 0.957 & 0.22 \\
& 295.2 & 32 & 1.52 & 0.905 & 0.23 \\
& 298.2 & 24 & 1.38 & 0.996 & 0.21 \\
\hline \hline
\end{tabular}


It must first be pointed out that the micelle aggregation number of $\mathrm{CTAB}$ in pure water at $298.2 \mathrm{~K}$ is in good agreement with values previously determined by using SSPF and CPC as the quencher $[16,43]$. Secondly, it can be seen that the micelle aggregation number (Table 2) decreases with increasing ACN content at a particular temperature. A similar trend was obtained for $\mathrm{CTAB}$ by the addition of some other polar organic solvents, such as ethanol [18] and glycerol [43]. The obtained results suggest that ACN acts as a structure breaker of the ordered water molecules around the micelle, which is a phenomenon generally observed for organic solvents. As the concentration of $\mathrm{ACN}$ increases, the proportion of $\mathrm{ACN}$ that replaces water molecules in the micelle solvent shell increases as well, causing the increase in the surface area per head group of CTAB and decrease in the aggregation number. Despite the fact that the mentioned trend of $N_{\text {agg }}$ changing with the increase in ACN concentration has not been observed at a temperature of $298.2 \mathrm{~K}$ (Table 2), a rough decrease in $N_{\text {agg }}$ can be noted with the increase in the ACN volume fraction.

The influence of acetonitrile on CTAB micellization can also be observed by considering two structural parameters of the micelle: the crosssectional area occupied by the hydrophilic group of the surfactant monomer at the micelle-solution interface (hereafter surface area per head group, $a_{0}$ ) and the critical aggregation parameter (hereafter packing parameter, $P$ ) [44]. The surface area per head group $a_{0}$ (or its inverse, the surface charge density) is the most significant factor that determines the micelle size, while the packing parameter is a controlling factor for the micellar shape $[18,42]$.

$P$ was calculated from the expression: $P=$ $\frac{v}{l_{\mathrm{C}} a_{0}}$, where $v$ is a volume occupied by the hydrophobic group in the micellar core (volume of the hydrocarbon chain of the surfactant monomer, i.e., the chain volume) while $l_{\mathrm{C}}$ is the length of the hydrophobic group in the micellar core (the critical chain length).

The values of $v\left(\right.$ in $\left.\mathrm{nm}^{3}\right)$ and $l_{\mathrm{C}}$ (in $\mathrm{nm}$ ) can be calculated using Tanford's empirical equation [45]:

$$
\begin{aligned}
& v=(0.0274+0.0269 n) \\
& l_{C}=(0.154+0.1265 n)
\end{aligned}
$$

where $n$ is the number of carbon atoms in the hydrocarbon tail of the surfactant monomer, which was taken to be 16 for CTAB.
Thus, assuming the CTAB micelles are spherical, we have estimated the micellar radius $\left(R_{0}\right)$ and surface area per head group $\left(a_{0}\right)$. The values of those micellar parameters are listed in Table 2. A change in the surface area per head group with respect to the ACN content is such that the $a_{0}$ values, roughly said, do increase with an increase in the $\mathrm{ACN}$ volume fraction at a constant temperature, which is in accordance with a reduction of $N_{\text {agg }}$ produced by the presence of $\mathrm{ACN}$ in the aqueous mixture. On the other hand, the $P$ values slightly decrease with an increase in the ACN volume fraction, while a change in $\mathrm{P}$ with temperature at a fixed volume fraction of ACN in the mixture seems to be basically negligible. However, from the values of $P$, one can predict the shape and type of the CTAB aggregates. The obtained $P$ value of CTAB in pure water as well as in ACN/WR mixtures at all temperatures was less than 0.333 , indicating a spherical shape of the micelle [44].

\section{CONCLUSION}

The micellization characteristics, such as the critical micellar concentration (CMC), degree of counter ion dissociation $(\alpha)$, micellar aggregation number $\left(N_{\mathrm{agg}}\right)$, and thermodynamics of micellization, of cetyltrimethylammonium bromide (CTAB) in acetonitrile/water mixtures were investigated using conductometric and steady-state fluorescence methods and by varying co-solvent composition as well as the temperature. At a fixed temperature, an increase in CMC and a decrease in $N_{\text {agg }}$ were observed with increasing acetonitrile (ACN) content in the solvent mixture. In ACN-poor mixtures $(10 \% \mathrm{v} / \mathrm{v})$, the $\mathrm{CMC}$ values increase with a temperature increase for both 15 and 20\% (v/v) ACN. The CMC value decreased up to the certain temperature $(295.2 \mathrm{~K})$, and then increased. In addition, the Krafft point $\left(T_{\mathrm{K}}\right)$ values of $\mathrm{CTAB}$ in $\mathrm{ACN} /$ water mixtures were generally found to be below the conventional value for $\mathrm{CTAB}$ in pure water, while for CTAB in $15 \%$ (v/v) ACN as well as in $20 \%(\mathrm{v} / \mathrm{v}) \mathrm{ACN}$, the large decrease of the $T_{\mathrm{K}}$ was obtained. Moreover, for a CTAB concentration above the CMC $\left(6.0 \times 10^{-2} \mathrm{M} \approx 60 \mathrm{CMC}\right)$ in the examined micellar systems, the hysteresis of conductivity with respect to temperature was noticed.

Acknowledgements. This work was partially supported by the Ministry of Education and Sciences of Serbia (grants no. 451-03-9/2021-14/200161 and 451-03-9/2021-14/200053). 


\section{REFERENCES}

[1] K. Holmberg, R. Laughlin, Surfactant science is growing: Editorial overview, Curr. Opin. Colloid Interface Sci. 2, 453-455 (1997). DOI: https://doi.org/10.1016/S1359-0294(97)80091-X

[2] Z. Khan, M. A. Malik, S. A. AL-Thabaiti, A. Alshehri, F. Nabi, Micellization and thermodynamic properties of cationic surfactant cetyltrimethylammonium bromide in non-aqueous mixture of lauric acid, Int. J. Electrochem. Sci. 12, 4528-4542 (2017).

DOI: https://doi: $10.20964 / 2017.05 .53$

[3] G. Kumar, M. S. Chauhan, Conductometric investigations of surfactant behavior in aqueous polar aprotic organic additives, J. Mol. Liq. 249, 710-715 (2018). DOI: https://doi.org/10.1016/j.molliq.2017.11.090.

[4] L. L. Schramm, E. N. Stasiuk, D. G. Marangoni, Surfactants and their applications, Annu. Rep. Prog. Chem., Sect. C: Phys. Chem. 99, 3-48, (2003).

DOI: https://doi.org/10.1039/B208499F

[5] M. J. Rosen, Surfactants and Interfacial Phenomena, Wiley Interscience, New York, 2004.

[6] S. N. Blagojević, S. M. Blagojević, N. D. Pejić, Performance and efficiency of anionic dishwashing liquids with amphoteric and nonionic surfactants, J. Surfactants Deterg. 19, 363-372 (2016).

DOI: https://doi.org/10.1007/s11743-015-1784-5

[7] A. Domínguez, A. Fernández, N. González, E. Iglesias, L. Montenegro, Determination of critical micelle concentration of some surfactants by three techniques, $J$. Chem. Educ. 74, 1227-1231 (1997). DOI: https://doi.org/10.1021/ed074p1227.

[8] P. Hansson, B. Jönsson, C. Ström, O. Söderman, Determination of micellar aggregation numbers in dilute surfactant systems with the fluorescence quenching method, J. Phys. Chem. B, 104, 3496-3506 (2000). DOI: https://doi.org/10.1021/jp992444r

[9] J. Aguiar, P. Carpena, J. A. Molina-Bolivar, C. Carnero Ruiz, On the determination of the critical micelle concentration by the pyrene 1:3 ratio method, J. Colloid Interface Sci. 258, 116-122 (2003).

DOI: https://doi.org/10.1016/S0021-9797(02)00082-6

[10] C. C. Ruiz, Thermodynamics of micellization of tetradecyltrimethylammonium bromide in ethylene glycol-water binary mixtures, Colloid. Polym. Sci. 277, 701-707 (1999).

DOI: https://doi.org/10.1007/s003960050443

[11] H. Akbaş, C. Kartal, Conductometric studies of hexadecyltrimethylammonium bromide in aqueous solutions of ethanol and ethylene glycol, Colloid J. 68, 125-130 (2006).

DOI: https://doi.org/10.1134/S1061933X06020013

[12] A. Rodríguez, M. M. Graciani, M. L. Moyá, Effects of addition of polar organic solvents on micellization, Langmuir, 24, 12785-12792 (2008).

DOI: https://doi.org/10.1021/la802320s

[13] A. Shrivastava, K. K. Ghosh, Micellization of cetyl triphenyl phosphonium bromide surfactant in binary aqueous solvents, J. Surfactants Deterg. 11, 287-292 (2008). DOI: https://doi.org/10.1007/s11743-008-1083-5
[14] A. Rodríguez, M. M. Graciani, G. Fernández, M. L. Moyá, Effects of glycols on the thermodynamic and micellar properties of TTAB in water, J. Colloid Interface Sci. 338, 207-215 (2009). DOI: https://doi.org/10.1016/j.jcis.2009.06.005

[15] P. A. Kabir-ud-Din, P. A. Koya, Effect of acetonitrile on the micellization and thermodynamic parameters of tetradecyltrimethylammonium bromide: Conductometric and fluorimetric studies, J. Mol. Liq. 158, 111-116 (2011).

DOI: https://doi.org/10.1016/j.molliq.2010.11.003

[16] N. Dubey, CTAB aggregation in solutions of higher alcohols: Thermodynamic and spectroscopic studies, $J$. Mol. Liq. 184, 60-67 (2013). DOI: https://doi.org/10.1016/j.molliq.2013.04.022

[17] A. Janošević Ležaić, N. Paunović, N. Pejić, Thermodynamics of micellization of hexadecyltrimethylammonium bromide in propylene glycol-water mixture: a conductivity study, FU Phys. Chem. Tech. 12, 17-26 (2014). DOI: https://doi.org/10.2298/FUPCT1401017J

[18] W. Li, Y-C. Han, J-L. Zhang, B-G. Wang, Effect of ethanol on the aggregation properties of cetyltrimethylammonium bromide surfactant, Colloid J. 67, 159163 (2005).

DOI: https://doi.org/10.1007/s10595-005-0075-7

[19] I. Benito, M. A. Garcia, C. Monge, J. M. Saz, M. L. Marina, Spectrophotometric and conductometric determination of the critical micellar concentration of sodium dodecyl sulfate and cetyltrimethylammonium bromide micellar systems modified by alcohol and salts, Colloids Surf. A, 125, 221-224 (1997).

DOI: https://doi.org/10.1016/S0927-7757(97)00014-9

[20] F. Jalali, A. Gerandaneh, Micellization of cetyltrimethylammonium bromide (CTAB) in mixed solvents and in the presence of potassium bromide, J. Dispers. Sci. Technol. 32, 659-666 (2011).

DOI: https://doi.org/ 10.1080/01932691003800049

[21] J. Goronja, N. Pejić, A. Janošević Ležaić, D. Stanisavljev, A. Malenović, Using a combination of experimental and mathematical method to explore critical micelle concentration of a cationic surfactant, J. Chem. Educ. 93, 1277-1281 (2016).

DOI: https://doi.org/10.1021/acs.jchemed.5b00913

[22] J. Goronja, A. Janošević Ležaić, B. Dimitrijević, A. Malenović, D. Stanisavljev, N. Pejić, Determination of critical micelle concentration of cetyltrimethylammonium bromide: different procedures for analysis of experimental data, Hem. Ind. 70, 485-492 (2016). DOI: https://doi.org/10.2298/HEMIND150622055G

[23] P. K. Misra, B. K. Mishra, G. B. Behera, Micellization of ionic surfactants in tetrahydrofuran-water and acetonitrile-water mixed solvent systems, Colloids Surf. 57, 1-10 (1991). DOI: https://doi.org/10.1016/0166-6622(91)80175-N

[24] A. S. Kord, M. G. Khaledi, Controlling solvent strength and selectivity in micellar liquid chromatography: role of organic modifiers and micelles, Anal. Chem. 64, 1894-1900 (1992). DOI: https://doi.org/10.1021/ac00041a026

[25] A. Cifuentes, J. L. Bernal, J. C. Diez-Masa, Determination of critical micelle concentration values using capil- 
lary electrophoresis instrumentation. Analytical chemistry, Anal. Chem. 69, 4271-4274 (1997).

DOI: https://doi.org/10.1021/ac970696n

[26] P. Carpena, J. Aguiar, P. Bernaola-Galván, C. Carnero Ruiz, Problems associated with the treatment of conductivity-concentration data in surfactant solutions: simulations and experiments, Langmuir, 18, 6054-6058 (2002). DOI: https://doi.org/10.1021/la025770y

[27] C. Vautier-Giongo, B. L. Bales, Estimate of the ionization degree of ionic micelles based on Krafft temperature measurements, J. Phys. Chem. B, 107, 5398-5403 (2003). DOI: https://doi.org/10.1021/jp0270957

[28] J. Ž. Manojlović, The Krafft temperature of surfactant solutions, Therm. Sci. 16, S701-S710 (2012). DOI: https://doi.org/10.2298/tsci120427197m

[29] J. C. Roy, Md. N. Islam, G. Aktaruzzaman, The effect of $\mathrm{NaCl}$ on the Krafft temperature and related behavior of cetyltrimethylammonium bromide in aqueous solution, J. Surfactants Deterg. 17, 231-242 (2014). DOI: https://doi.org/10.1007/s11743-013-1510-0

[30] L. Piñeiro, M. Novo, W. Al-Soufi, Fluorescence emission of pyrene in surfactant solutions, Adv. Colloid Interface Sci. 215, 1-12 (2015).

DOI: https://doi.org/10.1016/j.cis.2014.10.010

[31] N. J. Turro, A. Yekta, Luminescent probes for detergent solutions. A simple procedure for determination of the mean aggregation number of micelles, J. Am. Chem. Soc. 100, 5951-5952 (1978).

DOI: https://doi.org/10.1021/ja00486a062

[32] L. G. Gagliardi, C. B. Castells, C. Ràfols, M. Rosés, E. Bosch, Static dielectric constants of acetonitrile/water mixtures at different temperatures and Debye-Hückel A and $\mathrm{a}_{0} \mathrm{~B}$ parameters for activity coefficients, J. Chem. Eng. Data 52, 1103-1107 (2007). DOI: https://doi.org/ 10.1021/je700055p

[33] H. Nazir, M. S. Ahanger, A. Akbar, Micellization of cationic surfactant cetyltrimethylammonium bromide in mixed water-alcohol media, J. Dispers. Sci. Technol. 30, 51-55 (2009). DOI: https://doi.org/ 10.1080/01932690802477264

[34] G. D Noudeh, M. Housaindokht, B. S. F. Bazzaz, The effect of temperature on thermodynamic parameters of micellization of some surfactants, J. Appl. Sci.7, 47-52 (2007). DOI: https://doi.org/10.3923/jas.2007.47.52

[35] S. Kumar, K Parikh, Influence of spacer on association behavior and thermodynamic parameters of dimeric cationic surfactants, Surfactants Deterg. 16, 739-749 (2013). DOI: https://doi.org/10.1007/s11743-013-1467-z

[36] A. K. Sood, R. Kaur, T. S. Banipal, Influence of organic solvents, head-groups and temperature on the micellar behavior of some cationic surfactants, Indian J. Chem. 55, 34-43 (2016).

[37] D. Atwood, A. T. Florence, Surfactants Systems: Their Chemistry, Pharmacy and Biology, Chapman and Hall, New York, 1983.

[38] R. Abdel-Rahem, Influence of glycerol and temperature on the phase behavior and micellization of CTAB and SDS in aqueous solutions, J. Dispers. Sci. Technol. 34, 932-940 (2013).

DOI: https://doi.org/10.1080/01932691.2012.731647

[39] Y. Moroi, Micelles: Theoretical and Applied Aspects, Springer US, New York, 1992.

[40] J. Luczak, C. Jungnickel, M. Joskowska, J Thöming, Thermodynamics of micellization of imidazolium ionic liquids in aqueous solutions $J$. Colloid Interf. Sci. 336, 111-116 (2009).

DOI: https://doi.org/10.1016/j.jcis.2009.03.017

[41] R. M. Pashley, M. E. Karaman, Applied Colloid and Surface Chemistry, Wiley\&Sons, United States, pp. 39, 2004.

[42] J. van Stam, S. Depaemelaere, F. C. De Schryver, Micellar aggregation numbers - A fluorescence study, $J$. Chem. Educ. 75, 93-98 (1998). DOI: https://doi.org/10.1021/ed075p93

[43] G. D'Errico, D. Ciccarelli, O. Ortona, Effect of glycerol on micelle formation by ionic and nonionic surfactants at $25{ }^{\circ} \mathrm{C}$, J. Colloid Interf. Sci. 286, 747-754 (2005). DOI: https://doi.org/10.1016/j.jcis.2005.01.030

[44] R. Nagarajan, Molecular packing parameter and surfactant self-assembly: the neglected role of the surfactant tail. Langmuir, 18, 31-38 (2002). DOI: https://doi.org/10.1021/la010831y

[45] C. Tanford, The Hydrophobic Effect, Wiley, New York, 1980. 